Права людини в Україні та у зарубіжних країнах:

проблеми теорії та нормативно-правової регламентації

DOI https://doi.org/10.36059/978-966-397-210-7/306-327

Міхальов В. О.,

доцент кафедри конституційного права

Національного університету «Одеська юридична академія»,

м. Odeca

\title{
КОНСТИТУЦЙНІ ПРИНЦИПИ, ЗАБОРОНИ І ГАРАНТІЇ ЯК ЕЛЕМЕНТИ ПРАВОВОГО СТАНОВИЩА ОСОБИСТОСТІ
}

Анотація. У цій науковій роботі розглядаються принципи, заборони та гарантії, які закріплені в Конституції України $i$ стосуються прав $i$ свобод особистості. Ці принципи характеризуються як ієрархічно побудована система, до складу якої входять три групи принципів. Першу групу принципів принципи конституційного ладу подано як систему загально соціальних гарантій, яка становить фундамент правового становища особистості. Запропоновано розподіл цих принципів на десять груп за певними підставами. Другу групу утворюють власне принципи правового становища особистості, які поділено на три групи. Третя група складається із принципів виборчого права. Заборони проаналізовані як спосіб правового регулювання, що знаходиться в нерозривному діалектичному зв'язку зі свободою, яка розглядається в якості принципу правового положення особистості і якості його гарантій. Юридичні гарантії у вигляді прав-гарантій, гарантій-заборон, та гарантії-обов'язку поділено на дві групи: гарантії реалізації та захисту прав і свобод особистості та гарантії, що виникають у питаннях, пов'язаних із притягненням людини до юридичної відповідальності.

\section{Вступ}

Останнім часом досить часто можна почути 3 вуст відносно великої частини політиків, політологів, соціологів, інших представників соціальних наук і навіть юристів, не кажучи вже про «простих» людей, про необхідність прийняття нової конституції, або внесення в 
чинну конституцію кардинальних змін. У першу чергу йдеться про реконструкцію юридичній організації держави, про вибір іншої форми правління, іншого територіального устрою, збільшення (зменшення) повноважень тих чи інших органів держави, засновування нових органів, союз і навіть приєднання до тих чи інших держав або державних об'єднань, тобто йдеться про владу та нові політичні, економічні, соціальні, ідеологічні орієнтири нової влади. Разом із тим нерідко згадують і про права людини, про необхідність модернізації, переробки і цих положень чинної Конституції України. Здається, що ці «модернізатори» не дуже ретельно ії читали чи не читали ії взагалі, що вони не знають або знають дуже приблизно про Загальну декларацію прав людини ООН, про міжнародні пакти про права людини, про Конвенцію Ради Європи про захист прав людини і основоположних свобод, про інші численні міжнародно-правові акти із приводу прав людини, що Україна приєдналась до абсолютної більшості цих документів, що порівняльний аналіз положень Конституції України із цими міжнародними актами показує, що на нормативному рівні в Україні запроваджені міжнародні стандарти прав людини.

Безумовно, життя не стоїть на місці, часто виникають нові виклики, в тому числі ті, що стосуються прав людини, i реагувати на них необхідно, проте відмовлятися від того, що вже напрацьовано, не можна. Головна проблема полягає в тому, що треба ретельно вивчати Основний Закон країни і запроваджувати в життя його положення, а серед тих положень, які стосуються прав людини, $є$ і те, на що не звертають увагу. Йдеться про такі елементи правового становища особистості, як принципи ії правового статусу, заборони певного виду діяльності, гарантії прав і свобод. Якщо вони не працюють, якщо на них не звертають уваги, то прав і свобод в особистості в державі не буде. Часто читач конституції пробігає ці положення поглядом, мовляв я це і так все добро знаю, тут немає нічого нового для мене. 
Права людини в Україні та у зарубіжних країнах:

проблеми теорії та нормативно-правової регламентації

\section{1. Правове становище особистості. Принципи конституційного ладу і принципи} правового становища особистості

Для визначення місця людини в системі соціальних зв'язків доцільно використовувати досить складну категорію - «правове становище особистості», центральним елементом якої $\epsilon$ категорія «правовий статус особистості» як система прав, свобод і обов'язків. В якості основних елементів, які передують цій системі, зумовлюють її, виступають: громадянські і правові статуси особистості, правоздатність та принципи правового становища особистості. Необхідно виділити і елементи, на яких вона базується. Це - загально-соціальні та спеціальні (юридичні) гарантії прав і свобод, як умови і засоби їх реалізації та захисту, без яких вони втрачають свій сенс, виступають як порожня нічим не підкріплена декларація.

Більшість вчених-конституціоналістів ототожнює поняття «конституційно-правове становище особистості» $\mathrm{i}$ «конституційно-правовий статус особистості». Дійсно, в перекладі 3 латинської мови термін «статус» зазвичай перекладається на українську як «становище». Проте розмежування цих термінів і надання кожному 3 них власного змісту підкреслює в терміні «конституційний статус особистості», права, свободи та обов'язки, що визначає місце людини в суспільстві і державі, в системі соціальних зв'язків. Разом із тим у межах більш широкого за обсягом терміна «правове становище особистості» з'являється можливість показати чинники, які зумовлюють той чи інший перелік прав, обов'язків, відповідальності у той чи іншій особи і ще підкреслити загальні і юридичні гарантії, які сприяють реалізації та захисту прав і свобод.

До того ж у Великому тлумачному словнику сучасної української мови поняття «становище» трактується як:

1. Ті чи інші обставини, умови, в яких хто-, що-небуть перебуває // Сукупність обставин, що створюють ту чи іншу ситуацію. 
2. Сукупність суспільно-політичних відносин, аспектів суспільного життя.

3. Місце, роль у суспільстві, в соціальному чи професійному середовищі, в сім'ї і. т. ін.

А поняття «статус» тлумачиться як:

1. У міжнародному праві - становище, стан // Певний стан чого-небудь.

2. Сукупність прав i обов'язків громадянина чи юридичної особи [1, с. 890, 895]. Отже, про повну тотожність цих термінів тут йдеться.

Уявляється, що саме термін «становище» більш доречний для того, щоби в одному понятті була показана в якості головного елементу сукупність прав і обов'язків, тобто правовий статус, а разом із тим показані інші обставини, аспекти життя, що створюють певну ситуацію, зумовлюють цей правовий статус.

Одним із головних елементів правового становища особистості є принципи.

Принципи права виконують роль початкових, визначальних ідей, які складають моральну та організаційну основу виникнення, розвитку і функціонування права. Вплив принципів на правовий статус вельми багатогранний. Саме принципи, їх реалізація свідчать про рівень забезпечення прав і свобод людини і громадянина. За ними можна судити про те, чи достатньо активна діяльність органів державної влади і місцевого самоврядування 3 дотримання та охорони прав і свобод особистості, що закріплені в Конституції та законах, чи існують будь-які межі в реалізації прав і свобод, чи допускаються їхні обмеження, чи функціонують законні механізми захисту прав особистості. Вони визначають основні риси статусу всіх членів суспільства, розповсюджуються на всі без виключення права, свободи і обов'язки, незалежно від того, якою галуззю права вони встановлені.

Характеризуючи структуру сучасної конституції, Т.Я. Хабрієва та В.Є. Чіркін пишуть, що «...перша глава сучасної конституції повинна бути присвячена суспільству, 
основним принципам цього найбільш широкого поняття, 3 яким людина нерозривно пов'язана. Людина, різні колективи, держава - все це існує і діє у суспільстві. Ця глава могла б називатися «Основи...» [2, с. 118]. У цій главі (розділу, частині) можна було б зафіксувати основні принципи економічної, соціальної, політичної системи, духовного життя суспільства ... У цій же главі важливо відобразити найважливіші положення про природу держави (демократична, соціальне і т.д.), як невід'ємної частини сучасного суспільства» [2, с. 119].

Фактично тут йдеться про основи будови суспільства i побудови держави, про сукупність принципів, на підставі яких повинні базуватися основоположні «конструкції» держави, які прямо або опосередковано стосуються правового становища особистості i завдають певний орієнтир їхньої деталізації безпосередньо в правах, свободах i обов'язках людини i громадянина. Але одночасно ці принципи виступають в якості загальносоціальних гарантій прав і свобод, оскільки «гарантії прав людини і громадянина - це умови і засоби, принципи та норми (курсив мій), які забезпечують здійснення, охорону і захист проголошених в конституції і законах прав і свобод» [3, с. 246]. У широкому розумінні «гарантії прав людини охоплюють всю сукупність об'єктивних і суб'єктивних факторів, що спрямовані на повну реалізацію і всебічну охорону і захист прав і свобод особистості, на усунення можливих причин та перешкод їх нездійснення» [4, с. 263].

Саме таким чином побудовано перший розділ чинної Конституції України.

Конституції належить особлива роль у встановленні принципів правового становища особистості. Ці принципи $\epsilon$ вихідними не тільки для визначення конституційного, а i в цілому загального правового статусу особистості. Основний Закон встановив більшість із цих принципів у чітких формулюваннях, що позитивно впливає на правове положення людини і громадянина. 
Конституційні принципи, що стосуються правового становища особистості, можна поділити на три групи, які пов'язані ієрархічним зв'язком.

Першу групу утворюють принципи основ конституційного ладу, які закріплені в Розділі I Основного Закону України. Вони встановлюють систему загальних (політичних, економічних, соціальних, культурних, та інших) гарантій правового становища особистості.

Уважно читаючи першій розділ Конституції України, можна побачити такі складові частини першої групи конституційних принципів - принципів-гарантій, які фактично виступають в якості загальних гарантій прав i свобод людини і громадянина:

Принципи, що встановлюють соціальний $i$ громадянський статус людини та ії відносини з державою. (cm. cm. 3,4):

1. Принцип визнання людини, ï̈ життя і здоров’я, честі і гідності, недоторканності і безпеки найвищою соціальною цінністю в Україні.

2. Принцип визначення змісту і спрямованості діяльності держави через права людини та їх гарантії.

3. Принцип відповідальності держави перед людиною за свою діяльність.

4. Принцип заборони узурпувати державою, її органами, або посадовими особами права народу визначати i змінювати конституційний лад в Україні.

5. Принцип проголошення, утвердження і забезпечення прав людини головним обов'язком держави.

6. Принцип єдиного громадянства.

Принципи, що встановлюють основи державного будівництва

України. (cm. 2, 5, 6, 7):

1. Принцип унітаризму.

2. Принцип республіканізму.

3. Принцип народного суверенітету i принцип народовладдя. 
4. Принцип заборони будь-кому узурпувати державну владу.

5. Принцип закріплення виключно за народом права визначати і змінювати конституційний лад в Україні.

6. Принцип розподілу влади.

7. Принцип визнання і гарантування місцевого самоврядування.

Принципи, що закладають основи правової системи $i$ основ правового порядку в Україні. (cm. cm. 8, 9, 19):

1. Принцип верховенства права.

2. Принцип найвищої юридичної сили норм Конституції України.

3. Принципи прийняття законів та інших нормативноправових актів на основі Конституції України.

4. Принцип прямої дії норм конституції України.

5. Принцип закріплення умов дії в Україні міжнародних договорів.

6. Принцип правового порядку в Україні: ніхто не може бути примушений робити те, що не передбачено законодавством.

7. Принципи діяльності органів державної влади, органів місцевого самоврядування та їх посадових осіб.

Принципи, що забезпечують розвиток $i$ захист мови $i$ культури в Україні (cm. cm. 10, 11, 12):

1. Принцип забезпечення всебічного розвитку i функціонування української мови у всіх сферах суспільного життя на території України.

2. Принцип гарантування в Україні вільного розвитку, використання і використання і захисту російської і інших мов національних меншин України.

3. Принцип сприяння 3 боку держави розвиткові української нації, її історичної свідомості, традицій і культури.

4. Принцип сприяння 3 боку держави вивченню мов міжнародного спілкування.

5. Принцип сприяння з боку держави консолідації та розвиткові української нації, іï̈ історичної свідомості, 
традицій і культури, а також самобутності всіх корінних народів і національних меншин.

6. Принцип задоволення національно-культурних i мовних потреб українців, які проживають за межами держави.

Принципи, що гарантують право власності і право користування природними ресурсами. (cm.cm. 13, 14):

1. Принцип визнання землі, iї надр, атмосферного повітря, водних та інших природних ресурсів в межах території України об’єктами права власності Українського народу.

2. Принцип можливості громадян користуватися природними об'єктами права власності народу.

3. Принцип забов'язального характеру власності і заборони ії використання на шкоду людині і суспільству.

4. Принцип гарантування захисту прав усіх суб'єктів права власності і господарювання.

5. Принцип визнання землі основним національним багатством.

6. Принцип гарантування права власності на землю.

Принципи заборони будь-якої обов'язкової ідеології, цензури, та гарантування свободи політичної діяльності. (cm. 15):

1. Принцип засад суспільного життя в Україні.

2. Принцип заборони визнання будь-якої ідеології обов'язковою.

3. Принцип заборони цензури.

4. Принцип гарантування свободи політичної діяльності, не забороненої Конституцією i законами України.

Принципи, що гарантують екологічну безпеку. (cm. 16):

1. Принцип забезпечення екологічної безпеки i підтримання екологічної рівноваги на території України.

2. Принцип подолання наслідків Чорнобильської катастрофи.

3. Принцип збереження Українського народу як обов'язок держави. 
Права людини в Україні та у зарубіжних країнах:

проблеми теорії та нормативно-правової регламентації

Принципи, які пов'язані із захистом України (ст. 17):

1. Принцип захисту суверенітету та територіальної цілісності України як найважливіші функції держави.

2. Принципи, які закріплюють завдання Збройних Сил України і відповідних військових формувань та правоохоронних органів держави.

3. Принцип заборони використання Збройних Сил України і інших військових формувань для обмеження прав і свобод громадян або повалення конституційного ладу, усунення органів влади чи перешкоджання їх діяльності.

4. Принцип соціального захисту громадян України, які перебувають на службі у Збройних Силах України та в інших військових формуваннях, а також членів їхніх сімей.

5. Принцип заборони створення і функціонування будьяких збройних формувань, не передбачених законом.

6. Принцип заборони розташування на території України іноземних військових баз.

Принципи зовнішньополітичної діяльності України. (cm. 18):

1. Принцип спрямування зовнішньополітичної діяльності України на забезпечення їі національних інтересів і безпеки.

2. Принцип підтримання Україною мирного i взаємовигідного співробітництва із членами міжнародного співтовариства за загальновизнаними принципами i нормами міжнародного права.

Саме ці принципи за умов їх суворого дотримання i створюють сприятливі обставини в усіх основоположних сферах суспільного життя для забезпечення прав, свобод i інтересів людини, тому вони одночасно і виступають в якості їхніх загальних гарантій.

Закріплений у ст. 3 принцип визнання людини, іï життя і здоров'я, честі і гідності, недоторканності і безпеки найвищою соціальною цінністю виступає фундаментальною основою по відношенню до другої групи конституційних принципів, які стосуються правового становища особистості і виражені в Розділі II Конституції України, якій 
власно і починається із закріплення принципів правового статусу особистості.

1. Принципи, що закріплюють основні засади прав $i$ свобод особистості (cm.cm. 21, 22, 23, 51):

1) принцип вільності і рівності всіх людей в їхній гідності і правах;

2) принцип непорушності і невідчужуваності прав i свобод людини;

3) принцип невичерпності прав і свобод людини i громадянина тими правами і свободами, що закріплені в Конституції;

4) принцип гарантування конституційних прав і свобод і неможливості їх скасування;

5) принцип недопущення звуження змісту та обсягу існуючих прав і свобод під час прийняття нових законів або внесення змін до чинних законів;

6) принцип, що закріплює право людини на вільний розвиток своєї особистості, якщо при цьому не порушуються права і свободи інших людей;

7) принцип наявності в кожної людини обов'язків перед суспільством;

8) принцип охорони сім'ï, дитинства, материнства i батьківства.

2. Принципи, що закріплюють принцип рівноправності та особливі обставини, які з ним пов'язані(ст.ст. 24, 26, 51, 52, 63):

1) принцип рівності конституційних прав i свобод громадян;

2) принцип рівності перед законом;

3) принцип рівності усіх суб’єктів власності перед законом;

4) принцип заборони привілеїв чи обмежень за різними ознаками;

5) принцип рівності прав чоловіка і жінки;

6) принцип рівності подружжя у шлюбі;

7) принцип рівності прав іноземців і осіб без громадянства, які на законних підставах перебувають в 
Україні 3 громадянами України за винятками, встановленим Конституцією, законами чи міжнародними договорами України;

8) принцип рівності дітей у своїх правах;

9) принцип рівності прав засудженого з правами інших осіб, за винятком обмежень, які визначені законом i встановлені вироком суду.

3. Принципи, що стосуються громадянських і правових станів особистості (cm. 25):

1) принцип неможливості позбавити громадянина України громадянства і права змінити громадянство;

2) принцип заборони виганяти громадянина України за іï̈ межи або видавати його іншій державі;

3) принцип гарантування з боку держави піклування і захисту громадянам України, які перебувають за її межами;

4) принцип можливості надання іноземцям і особам без громадянства притулку.

На відміну від першої групи принципів, принципів основ конституційного ладу, які мають загальний характер і на які, у зв'язку із цим, нерідко не звертають особливої уваги, друга група принципів безпосередньо наближена до особистості i тому їі треба сприймати як принципи правового становища особистості.

Третя група принципів закріплена у статті 71 Конституції України, встановлює принципи загального, рівного, прямого виборчого права, вільності виборів і таємного голосування. Очевидно, що принципи вільності і рівності прав усіх людей (ст.21) $є$ базовими по відношенню до принципів вільності виборів, а також загального і рівного виборчого права відповідно.

Демократичні принципи правового положення особистості, права і свободи людини і громадянина, на яких вони базуються, а також гарантії їх реалізації та захисту знаходяться в тісному взаємозв'язку і $\epsilon$ основою для нормального існування людини. За думкою Н.В. Вітрука, принципи юридичної конструкції правового становища особистості $\epsilon$ «особливим, специфічним елементом...» який 
визначає «...сутність і зміст правового положення особистості та його структурних елементів». Вони «...складають теоретико-методологічний та правовий стрижень правового положення особистості...цементують, об'єднують в одне ціле комплекс структурних елементів правового положення особистості, надають філософськоідеологічне його обгрунтування» [5, с. 88].

\section{2. Конституційні принципи-заборони як спосіб правового регулювання}

Само правове становище особистості встановлюється за допомогою законодавчого закріплення уповноважуючих, зобов'язуючих або забороняючих правових норм, які визначають модель правомірної поведінки їхніх учасників. Цими нормами закріплені дозволяння, зобов'язання та заборони. Якщо звернутися до Конституції України, то можна виявити, що ні в найменуванні другого розділу «Права, свободи i обов'язки людини i громадянина», ні в найменуванні інших розділів заборони як способи впливу на суспільне життя не вказані зовсім, і складається уявлення, що вони в неї або взагалі відсутні, або законодавець не використовує цей термін, оскільки заборона в суспільній свідомості асоціюється негативно, як обмежування свободи. Між тим пильне ознайомлення з текстом Основного Закону України дозволяє побачити більше чотирьох десятків подібного роду установлень, і в першу чергу це стосується основ конституційного ладу, своєрідного фундаменту всієї правової системи України, які виступають передусім в якості бази основоположних начал правового становища особистості (Розділ 1 Конституції України) та власне основ правового становища особистості (Розділ 2 Конституції України). Якщо звернутися до Конституції України, то можна виявити, що ні в найменуванні другого розділу «Права, свободи i обов'язки людини i громадянина», ні в найменуванні інших розділів заборони як способи впливу на суспільне життя не вказані зовсім, і складається уявлення, що 
вони в неї або взагалі відсутні, або законодавець не використовує цей термін, оскільки заборона в суспільній свідомості асоціюється негативно, як обмежування свободи. Між тим пильне ознайомлення з текстом Основного Закону України дозволяє побачити більше чотирьох десятків подібного роду установлень, і в першу чергу це стосується основ конституційного ладу, своєрідного фундаменту всієї правової системи України, які виступають передусім в якості бази основоположних начал правового становища особистості (Розділ 1 Конституції України) та власне основ правового становища особистості (Розділ 2 Конституції України).

Зобов'язання та заборони розглядаються як дві близькі за суттю категорії. Проте якщо зобов'язання передбачає певне обтяження, що пов'язане з необхідністю виконання тої чи іншої дії, то заборона, навпаки, полягає в утриманні від вчинення встановленої в забороні дії. Водночас дозволяння і заборони на перший погляд виглядають як абсолютно несумісні один з одним методи в механізмі правового регулювання, що визначають систему прав i свобод. Проте заборона як спосіб правового регулювання знаходиться у нерозривному діалектичному зв'язку зі свободою, що розглядається в якості принципу правового положення особистості. Принцип свободи іноді розподіляють на дві складові: «свобода для...» та «свобода від...». Перша з них знаходить своє відображення, своє розгортання в системі позитивних потенційних можливостей для людини, які юридично виражаються через систему суб'єктивних прав, свобод i законних інтересів людини, а друга отримує свій розвиток в системі заборон від можливих несприятливих впливів на людину $з$ боку інших суб'єктів правовідносин: держави, групи осіб, окремих людей. Це певні «зони небезпеки», тобто такі області життя кожної людини, вторгнення в які для інших суб'єктів без їі добровільної згоди на це суперечить правам, свободам і інтересам даної особи, а тому неприпустиме, крім випадків, визначених законом, та які у зв'язку із цим 
Права людини в Україні та у зарубіжних країнах:

проблеми теорії та нормативно-правової регламентації

огороджені своєрідною «юридичною огорожею» заборонами. Вони органічно «уплетені» в систему прав та свобод особистості та охороняють людину від цих несприятливих для нього діянь.

Принципи конституційного ладу та принципи правового положення особистості, що закріплені в перших трьох розділах Конституції України, виражені як через позитивні визначення, наприклад, «людина, іiї життя i здоровя, честь і гідність, недоторканність і безпека визнаються в Україні найвищою соціальною цінністю», (ст. 3, ч. 1), так і через деякі заборони, наприклад: «Ніхто не може узурпувати державну владу» (ст. 5, ч. 4).

Досліджуючи дану проблематику, С.С. Алексєєв прийшов до висновку про те, що по певному колу питань «...принцип ...права не тільки слугує підставою для введення загальних заборон, але, по суті справи, вони злилися та виступають у вигляді єдиного принципазаборони» [6, с. 235].

Заборони в Конституції України закріплені за допомогою таких лексичних конструкцій: «право...не може...» (ст. 5, ч. 3), «ніхто не може...» (ст.ст. 5, ч. 4; 19, ч. 1 ; 27 , ч. $2 ; 28$, ч. $2 ; 29$, ч. $2 ; 32$, ч. $1 ; 35$, ч. $4 ; 36$, ч. $4 ; 41$, ч. $4 ; 44$, ч. $3 ; 47$, ч. $3 ; 54$, ч. $2 ; 58$, ч. $2 ; 61$, ч. 1 ), «...не повинна використовуватися...» (ст. 13,ч. 3), «...не може...» (ст. 15, ч. 2; ст. 24 , ч. 2 ; 25 ,ч. 2 ; 35,ч. 3; ст. 41, ч. 7; 49, ч. 3), «..заборонена» (ст. 15, ч. 3) «...не можуть бути використані...» (ст. 17, ч. 4), «...забороняється...» (ст. 17, ч. 6; ст. 43, ч. 3 ; 43, ч. 5), «...забороняються» (ст. 37,1$)$, «...не допускається...» (ст.ст. 17 , ч. $7 ; 22$, ч. $3 ; 30$, ч. $2 ; 32$, ч. $2 ; 37$, ч. 3 ; ст. 42 , ч. 3), «...не можуть бути скасовані» (ст. 22, ч. 2), «громадянин...не може...» (ст. 25, ч. 1, ч. 2; ст. 33, ч. 2), «жодна людина...не може...» (ст. 28, ч. 3), «...не можуть мати...» (ст. 37, ч. 2), «...ніким не може...» (ст. 50, ч. 2), «...переслідується за законом» (ст. 52, ч. 2), «...не можуть бути обмежені...» (ст. 64, ч. 1, ч.2) «не мають права...» (ст. 70, ч. 1).

Конституція України запроваджує такі заборони: 
- заборона на скасування конституційних прав і свобод (ст. 22, ч. 2);

- заборона на звуження змісту та обсягу наявних прав і свобод під час прийняття нових законів (ст. 22, ч. 3);

- заборона на існування привілеїв та обмежень за ознаками раси, кольору шкіри, політичних, релігійних та інших переконань, статі, етнічного та соціального походження, майнового стану, місця проживання, за мовними або іншими ознаками (ст. 24, ч. 2);

- заборона на позбавлення громадянина України громадянства і права змінити громадянство (ст. 25, ч. 1);

- заборона на вигнання громадянина України за межі України або видання іншій державі (с. 25, ч. 2);

- заборона на свавільне позбавлення людини життя (ст. 27, ч. 2);

- заборона на піддавання людини катуванню, жорстокому, нелюдському, або такому, що принижують його гідність, поводженню чи покаранню покаранню (ст. 28, ч. 2);

- заборона на піддавання людини без їі згоди медичним, науковим або іншим дослідам (ст. 28, ч. 3);

- заборона на арешт людини або утримання іï під вартою інакше як за вмотивованим рішенням суду і тільки на підставах та в порядку, встановлених законом. (ст. 29, ч. 2);

- заборона на проникнення до житла чи іншого володіння особи, проведення в них огляду чи обшуку інакше як за вмотивованим рішенням суду. (ст. 30, ч. 2);

- заборона на втручання в особисте і сімейне життя людини, крім випадків, передбачених Конституцією України (ст. 32, ч. 1);

- заборона на збір, зберігання, використання та поширення конфіденційної інформації про особу без ії згоди, крім випадків, визначених законом, і лише в інтересах національної безпеки, економічного добробуту та прав людини (ст. 32, ч. 2); 
- заборона на позбавлення громадянина України права в будь-який час повернутися в Україну (ст. 33, ч. 2);

- заборона на визнання державою жодної релігії як обов'язкової (ст. 35, ч. 3);

- заборона на увільнення людини від своїх обов'язків перед державою або відмовлення від виконання законів за мотивами релігійних переконань (ст. 35, ч. 4);

- заборона на примушення людини до вступу в будьяке об'єднання громадян чи обмеження у правах за належність чи неналежність до політичних партій або громадських організацій (ст. 36, ч. 4);

- заборона на утворення і діяльність політичних партій та громадських організацій, програмні цілі або дії яких спрямовані на ліквідацію незалежності України, змісту конституційного ладу насильницьким шляхом, порушення суверенітету і територіальної цілісності держави, підрив ії безпеки, незаконне захоплення влади, пропаганду війни, насильства, на розпалювання міжетнічної, расової, релігійної ворожнечі, посягання на права i свободи людини, здоров'я населення (ст. 37, ч. 1);

- заборона на наявність воєнізованих формувань у політичних партій та суспільних організацій (ст. 37, ч. 2);

- заборона на створення і діяльність організаційних структур політичних партій в органах виконавчої і судової влади i виконавчих органах місцевого самоврядування, військових формуваннях, а також на державних підприємствах, у навчальних закладах та інших державних установах і організаціях (ст. 37, ч. 3);

- заборона на протиправне позбавлення людини права власності (ст. 41, ч. 4);

- заборона на використання власності для завдання шкоди правам, свободам і гідності громадян, інтересам суспільства, погіршення екологічної ситуації та природної якості землі (ст. 41, ч. 7);

- заборона на зловживання монопольним становищем на ринку, неправомірне обмеження конкуренції та недобросовісну конкуренцію (ст. 42, ч. 3); 
Права людини в Україні та у зарубіжних країнах:

проблеми теорії та нормативно-правової регламентації

- заборона на використання примусової праці (ст. 43, ч. 3);

- заборона на використання праці жінок та неповнолітніх на небезпечних для їхнього здоров'я роботах (ст. 43 , ч. 5);

- заборона на примушення до участі або неучасті у страйку (ст. 44, ч. 3);

- заборона на примусове позбавлення житла інакше, як на підставі закону за рішенням суду (ст. 47, ч. 3);

- заборона на скорочення наявної мережі державних i комунальних закладів охорони здоров'я (ст. 49, ч. 3);

- заборона на засекречення інформації про стан довкілля, про якість харчових продуктів і предметів побуту (ст. 50, ч. 2);

- заборона на будь-яке насильство над дитиною та ії експлуатацію (ст. 52, ч. 2);

- заборона на використання i поширювання результатів інтелектуальної, творчої діяльності без згоди автора, за винятками, встановленими законом (ст. 54, ч. 2);

- заборона на відповідальність людини за дії, які під час їх вчинення не визнавалися законом як правопорушення (ст. 58, ч. 2);

- заборона на притягнення людини до юридичної відповідальності одного виду двічі за одне й те саме правопорушення (ст. 61, ч. 1);

- заборона на піддавання кримінальному покаранню особи за вчинення злочину, доки її вину не буде доведено в законному порядку і встановлено обвинувальним вироком суду (ст. 62, ч. 1);

- заборона на обвинувачення особи, яке грунтується на доказах, одержаних незаконним шляхом, а також на припущеннях (ст. 62, ч. 3);

- заборона на обмеження прав i свобод людини i громадянина, крім випадків, передбачених Конституцією України (ст. 64, ч. 1);

- заборона обмежувати права і свободи, передбачені статтями $24,25,27,28,29,40,47,51,52,55,56,57,58,59,60$, 61, 62, 63 Конституції України (ст. 64, ч. 2). 
У першому розділу Конституції України «Загальні засади» заборони-принципи закріплені в таких статтях: ст. 5 , ч. 3 ; ст. 5 ч. 4 ; ст. 13 , ч. 3 ; ст. 15 , ч. 2 ; ст. 15 , ч. 3 ; ст. 17 , ч. 4 ; ст. 17 , ч. 6 ; ст. 17 , ч. 7 ; ст. 19 , ч. 1.

Деякі із цих статей прямо звернені не до особистості, а до держави, ïï органів або посадових осіб чи до народу України. Проте, виходячи 3 ідеї одного із співавторів Декларації прав людини і громадянина 1789 р. абата Е.Ж. Сійєса, що «будь-який суспільний союз, і отже, будьяке політичне установлення може мати предметом лише проголошення, розповсюдження та забезпечення прав людини і громадянина» (цит. по [7, с. 117]), уявляється можливим включити їх у перелік заборон, які визначають основи правового становища особистості.

\section{3. Юридичні гарантії прав і свобод особистості}

У свій час К. Маркс писав, що «на бумазі легко можна прокламувати конституції, право кожного громадянина на освіту, на працю, і передусім на певний мінімум засобів існування. Але тим, що всі ці великодушні побажання записані на бумазі зроблено, ще не все: залишається ще одна задача запліднення цих ліберальних ідей матеріальними та розумними соціальними запровадженнями» (Цит. по: [8, с. 179]). Цю задачу закликані виконувати гарантії прав і свобод.

Гарантії прав людини і громадянина - це умови та засоби, що забезпечують можливість користуватися правами, які встановлені в конституції і законах держави. У широкому розумінні під поняттям «гарантії прав людини» розуміється сукупність об'єктивних та суб'єктивних факторів, які спрямовані на повну реалізацію та всебічну охорону прав і свобод особистості, на усунення можливих причин і обставин їх здійснення.

Більшість гарантій у вигляді умов спрямовані на забезпечення сприятливої обстановки, в атмосфері якої громадянин може ефективно користуватися своїми конституційними правами і свободами. Такі умови створюють зовнішнє середовище діяльності кожної людини і 
не залежать від його волі і побажань, оскільки вони іманентно притаманні суспільному і державному ладу.

Усі гарантії прав людини поділяють на загальні (загально-соціальні) та спеціальні (юридичні). Загальні гарантії - це система ідеологічних, економічних, політичних, духовних та інших відносин, умов, факторів, що задекларовані в основному законі, без яких вимоги особистості до суспільства носили би суто формальний характер (про них йшлося у \&1). Спеціальні (юридичні) гарантії - це встановлені державою 3 наданням їм формальної (юридичної) обов'язковості принципи і норми, які забезпечують здійснення зазначених прав і свобод шляхом належної регламентації порядку їх здійснення, а також їх охорони і захисту.

Найбільший за кількістю статей (21-68) другий розділ Конституції України «Права, свободи і обов’язки людини і громадянина», незважаючи на назву, містить у собі й інші елементи правового становища особистості, а саме його принципи, заборони i юридичні гарантії, притому останнім присвячено не лише окремі статті (принципи встановлено статтями 21-26, а юридичним гарантіям відведено статті 55-64). Ці гарантії можна знайти у других за рахунком i наступних частинах відповідних статей, які закріплюють те чи інше основне право. За невеликим винятком майже у всіх статтях, в яких закріплено права і свободи особистості, закріплені і їхні гарантії. При цьому нерідко буває, що один вз елементів тісно пов'язаний 3 іншим, i тоді для того, щоб підкреслити наявність присутності кожного 3 них, можуть використовуватися подвійні назви: принципи-гарантії, принципи-заборони; гарантії-заборони, права-гарантії, гарантії-обов'язки тощо.

Юридичні гарантії прав і свобод людини і громадянина, що закріплені у другому розділі Конституції України, можуть бути поділені на дві групи.

1. Юридичні гарантії реалізації та захисту конституційних прав і свобод особистості:

- право знати свої права і обов'язки (ст. 57, ч. 1); 
- право на судовий захист прав та свобод людини i громадянина (ст. 55, ч. 1);

- право на оскарження в суді рішень, дій чи бездіяльності органів державної влади, органів місцевого самоврядування, посадових і службових осіб (ст. 55, ч. 2);

- право на звернення за захистом своїх прав до Уповноваженого Верховної Ради України з прав людини (ст. 55, ч. 3);

- право на звернення за захистом своїх прав із конституційною скаргою до Конституційного Суду України з підстав, встановлених Конституцією України, в порядку, визначеному законом (ст. 55, ч. 4);

- право після використання всіх національних засобів юридичного захисту звертатися за захистом своїх прав і свобод до відповідних міжнародних судових установ чи до відповідних органів міжнародних організацій, членом або учасником яких є Україна (ст. 55, ч. 5) ;

- право будь-якими не забороненими законом засобами захищати свої права і свободи від порушень та протиправних посягань (ст. 55, ч. 6);

- право на відшкодування за рахунок держави чи органів місцевого самоврядування матеріальної та моральної шкоди, завданої незаконними рішеннями, діями, або бездіяльністю органів державної влади, органів місцевого самоврядування, їхніх посадових і службових осіб під час здійснення ними своїх повноважень (ст. 56);

- обов'язок держави довести закони та інші нормативно-правові акти, що визначають права і обов'язки громадян, до відома населення в порядку, встановленому законом (ст. 57, ч. 2).

- право на професійну правничу допомогу і свободу вибору захисника своїх прав (ст. 59);

- заборона обмеження конституційних прав і свобод, крім випадків, передбачених Конституцією України (ст. 64, ч. 1).

2. Права-гарантії, та гарантії-заборони, що виникають у питаннях, пов'язаних із притягненням людини до юридичної відповідальності: 
- заборона зворотної дії законів та інших нормативноправових актів у часі, крім випадків, коли вони пом'якшують або скасовують відповідальність особи (ст. 58, ч. 1);

- заборона відповідати за діяння, які на час їх вчинення не визнавалися законом як правопорушення (ст. 58, ч. 2);

- право не виконувати явно злочинне розпорядження чи накази (ст. 60, ч. 1);

- заборона бути двічі притягнутим до юридичної відповідальності одного виду за одне й те саме правопорушення (ст. 61, ч.1);

- право на презумпцію невинуватості (ст. 62, ч. 1);

- заборона будь-кому доводити свою невинуватість у вчиненні злочину (ст. 62, ч. 2);

- заборона грунтувати обвинувачення на доказах, одержаних незаконним шляхом, а також на припущеннях (ст. 62, ч. 3)

- право в разі вироку суду як неправосудного відшкодування державою матеріальної і моральної шкоди, завданої безпідставним засудженням;

- право підозрюваного, обвинуваченого чи підсудного на захист (ст. 62, ст. 4);

- право не давати показання або пояснення щодо себе, членів сім'ї чи близьких родичів (ст. 63, ч. 1).

- право підозрюваного, обвинуваченого чи підсудного на захист (ст. 63, ч. 2).

\section{Висновки}

Як і в кожній системі, у правовому становищі особистості всі елементи, які її складають, не тільки тісно пов'язані між собою, взаємно доповнюють один одного, але разом із тим кожний із низ має своє призначення, виконує певну функцію. Принципи, заборони та гарантії правового становища не можна розглядати як другорядні елементи цієї системи, кожен із них одночасно виступає і у власній «ролі», і має ознаки іншої. Так, принципи несуть у собі не лише заряд визначальних ідей, але й гарантій прав i свобод, а інколи вони виражені через заборони. Заборони в системі прав і свобод особистості виступають у вигляді 
гарантій певних прав, забороняють такі моделі поведінки людини, які несумісні із правопорядком, зі справедливістю, із правами та свободами інших членів суспільства, а юридичні гарантії нерідко закріплені в Конституції як права.

Дотримання принципів конституційного ладу i принципів правового становища особистості, виконання вимог закону щодо заборон та гарантій стане надійним фундаментом для забезпечення прав і свобод людини і громадянина.

\section{Список використаних джерел:}

1. Великий тлумачний словник сучасний словник сучасної української мови. Київ : Ірпень : ВТФ «Перун», 2001. 1440 c.

2. Хабриева Т.Я., Чиркин В.Е. Теория современной конституции. Москва : Норма, 2005. 320 с.

3. Рабінович П.М., Хавронюк М.I. Права людини і громадянина : навч. посібник. Київ : Атіка, 2004. 464 с.

4. Головистикова А.Н., Грудцына Л.Ю. Права человека. Москва : Эксмо, 2008. 448 с.

5. Витрук Н.В. Основы теории правового положения личности. Москва : Норма, 2008. 488 с.

6. Алексеев С.С. Общие дозволения и общие запреты в советском праве. Москва : Юрид.лит., 1989. 288 с.

7. Конституция в XX1 веке: сравнительно-правовое исследование. Москва : Норма: ИНФРА-М, 2011. 655 с.

8. Тодика Ю.Н., Тодыка О.Ю. Конституционно-правовой статус человека и гражданина в Украине. Киев : Концерн «Видавничий дім «Ін Юре», 2004. 368 с. 